April 2007

\title{
Semantics or Substance? David Scheffer's Welcome Proposal to Strengthen Criminal Accountability for Atrocities
}

William A. Schabas

\section{Recommended Citation}

Schabas, William A. (2007) "Semantics or Substance? David Scheffer's Welcome Proposal to Strengthen Criminal Accountability for Atrocities," Genocide Studies and Prevention: An International Journal: Vol. 2: Iss. 1: Article 4.

Available at: https://digitalcommons.usf.edu/gsp/vol2/iss1/4

This Articles is brought to you for free and open access by the Open Access Journals at Digital Commons @ University of South Florida. It has been accepted for inclusion in Genocide Studies and Prevention: An International Journal by an authorized editor of Digital Commons @ University of South Florida. For more information, please contact digitalcommons@usf.edu. 


\title{
Semantics or Substance? David Scheffer's Welcome Proposal to Strengthen Criminal Accountability for Atrocities
}

\author{
William A. Schabas \\ Professor of Human Rights Law, National University of Ireland, \\ Galway; Director, Irish Centre for Human Rights
}

David Scheffer's fascinating proposal, if I understand it properly, calls for an amalgamation of various categories of internationally condemned behavior-mainly genocide, crimes against humanity, and war crimes-into a new concept known as "atrocity law." This will facilitate implementation of the responsibility to protect vulnerable populations. Pedantic debates about matters of essentially technical relevance to criminal prosecution will not be allowed to impede sincere efforts at intervention or to provide a pretext for those who shirk their obligations. Leslie Green mooted a similar idea in the mid-1990s, but it didn't gain any traction at the time. ${ }^{1}$ In informal discussions as part of the drafting of the Rome Statute of the International Criminal Court (ICC), I argued for Green's proposal to conflate crimes against humanity and war crimes but was regularly told that this simply wasn't going to fly.

And yet there are many recent developments favoring this drive for greater coherence and more simplicity. The international tribunals themselves have promoted the idea of general principles and concepts with respect to war crimes that are drawn from such formulations as common article 3 of the 1949 Geneva Conventions. In effect, common article 3 serves as a catchall category that obviates the need for more precise provisions. The Appeals Chamber of the International Criminal Tribunal for the former Yugoslavia (ICTY) took two texts drawn from provisions drafted in the 1940s and "interpreted" them to mean all "serious violations of international humanitarian law." We can see the same kind of consolidation in the tendency of the tribunals to convict offenders of both crimes against humanity and war crimes. With rare exceptions, every "atrocity" committed in Bosnia and Herzegovina was characterized as both a war crime and a crime against humanity. Without suggesting that the distinction is devoid of any significance, in terms of putting evildoers behind bars it has not proven to be a terribly productive nuance. Much the same can be said of the distinction between genocide and crimes against humanity. The commission of inquiry into Darfur concluded against a finding of genocide but said that crimes against humanity appeared to have been committed and that there was no reason to suggest that this made the matter any less serious:

The above conclusion that no genocidal policy has been pursued and implemented in Darfur by the Government authorities, directly or though the militias under their control, should not be taken as in any way detracting from, or belittling, the gravity of the crimes perpetrated in that region. As stated above genocide is not necessarily the most serious international crime. Depending upon the circumstances, such international offences as crimes against humanity or large scale war crimes may be no less

William A. Schabas, "Semantics or Substance? David Scheffer's Welcome Proposal to Strengthen Criminal Accountability for Atrocities." Genocide Studies and Prevention 2, 1 (April 2007): 31-36. (C) 2007 Genocide Studies and Prevention. 
serious and heinous than genocide. This is exactly what happened in Darfur, where massive atrocities were perpetrated on a very large scale, and have so far gone unpunished. ${ }^{3}$

On the political level, there is also a marked tendency toward consolidation of the categories of international crime. The "Outcome Document" adopted in September 2005 by the United Nations Summit of Heads of State and Government affirmed a radical new international obligation when it declared that there was a "responsibility to protect populations from genocide, war crimes, ethnic cleansing and crimes against humanity." In other words, in this most contemporary and authoritative statement of the parameters of intervention to protect human rights, the member states of the United Nations have agreed that the responsibility to protect applies to a broad category of "atrocity," without distinction.

Is Scheffer proposing that we simply abandon the term "genocide" in favor of "atrocity" (something that would require a change to the name of this journal!)? Not quite, it appears, because he also argues for the term "precursors of genocide," which seems to be a kind of halfway house. The rationale for diluting the requirements of full-blown genocide into a list of "precursors" is to justify intervention, that is, implementation of the responsibility to protect. Instead of dawdling about definitional aspects of genocide, explains Scheffer, we should rapidly reach the less difficult conclusion that "precursors of genocide" are present and get on with the business of saving lives and protecting the innocent. But given the far-reaching principle confirmed in the Outcome Document, is this really necessary anymore? The so-called precursors will invariably fall into the other three categories recognized by the Summit of Heads of State and Government, namely crimes against humanity, war crimes, and ethnic cleansing. And, since there is a responsibility to protect when these are evident, does "precursors of genocide" really add anything?

The Outcome Document might well have used the term "atrocity" as a synonym for "genocide, war crimes, ethnic cleansing, and crimes against humanity." By my reading of Scheffer's proposal, he would be happy enough if we conceded that the two expressions describe the same reality. Certainly they appear to have much the same legal significance.

A historical approach is helpful in understanding why Scheffer's proposal may well be an idea whose time has come. Although a continuing distinction between genocide, crimes against humanity, and war crimes may have little or no legal significance today, an examination of the development of these concepts explains why the classifications exist (and also why the classifications are less and less important). In 1943, the UN War Crimes Commission was established by the Allies, for whom the end of the war was already in sight. They were determined to hold the Nazis personally accountable for the crimes they had committed. The name of the commission says it all: it was to prosecute "war crimes," a category whose parameters were well understood in international law. In effect, "war crimes" amounted to battlefield offences, committed amongst combatants, such as the use of prohibited weapons, or treachery, or the abuse of prisoners of war. "War crimes" also covered violations perpetrated against civilian nationals of an occupied territory. Full stop. When non-governmental organization activists asked the War Crimes Commission what would be done with respect to Nazi atrocities committed within Germany against German nationals, they were told this was simply beyond the scope of international law.

Rather quickly, the debate evolved, and there was growing willingness to contemplate prosecution of what were initially called "persecutions, exterminations 
and deportations" of "any civilian population." Sometimes, the experts also called them "atrocities," perhaps the first technical use of the term that Scheffer now proposes to place at the center of international humanitarian law or, rather, to give its own rubric, "atrocity law." The Allies ultimately agreed to try the Nazis for such crimes, which they labelled "crimes against humanity" in the charter of the Nuremberg Tribunal. ${ }^{5}$ Nervous about the danger that this would set a precedent by which Britain, France, the United States, and the Soviet Union might themselves be held responsible for "persecutions, exterminations and deportations" of their own subject peoples, the victorious Allies added a condition for the prosecution of "crimes against humanity": they had to be committed in the context of an international armed conflict. This was explained at the London Conference rather candidly by Justice Robert Jackson, the representative of the United States:

It has been a general principle of foreign policy of our Government from time immemorial that the internal affairs of another government are not ordinarily our business; that is to say, the way Germany treats its inhabitants, or any other country treats its inhabitants is not our affair any more than it is the affair of some other government to interpose itself in our problems. The reason that this program of extermination of Jews and destruction of the rights of minorities becomes an international concern is this: it was a part of a plan for making an illegal war. Unless we have a war connection as a basis for reaching them, I would think we have no basis for dealing with atrocities. They were a part of the preparation for war or for the conduct of the war in so far as they occurred inside of Germany and that makes them our concern. ${ }^{6}$

Jackson added the reason for the reluctance of the United States to extend the concept of "crimes against humanity" to acts committed in peacetime: "We have some regrettable circumstances at times in our own country in which minorities are unfairly treated." The British, French, and Russians obviously shared such concerns.

This narrow scope of "crimes against humanity"—or "atrocities," to use Scheffer's preferred nomenclature-was confirmed in the judgment of the International Military Tribunal at Nuremberg. Although there was much evidence of pre-war atrocities, the tribunal only found Nazi leaders guilty of crimes against humanity perpetrated after 1 September 1939, when the war began. ${ }^{8}$ This hypocritical limitation on crimes against humanity did not sit well with many smaller states, bound by their colonial heritage. At the first session of the UN General Assembly, in the weeks that followed the Nuremberg judgment, they set aside the term "crimes against humanity" and instead insisted that a cognate category of international crime be developed, one that would have no nexus with war. Cuba's Ernesto Dihigo, who directed the initiative, told the General Assembly that the Nuremberg trials had precluded punishment of certain atrocities because they had been committed before the beginning of the war. Fearing they might remain unpunished owing to the principle of nullum crimen sine lege, the representative from Cuba asked that "genocide" be declared an international crime. ${ }^{9}$ The process concluded two years later in the adoption of the Convention on the Prevention and Punishment of the Crime of Genocide (UNCG). Article 1 of the UNCG declares that genocide can be committed "in time of peace or in time of war."10

The difference between "crimes against humanity" and "genocide," then, was that the former could only be committed "in time of war." Of course, the two categories of international crime were also defined somewhat differently. Whereas "crimes against humanity" covered a broad range of acts of persecution and other atrocities, directed against any civilian population, "genocide" was confined to the intentional destruction 
of a limited catalogue of protected groups. This had been the price of the UNCG: states would only agree to the international criminalization in peacetime of an extreme form of atrocity. For these reasons, there was no Convention on Crimes against Humanity, a gap in international law that was really only closed with the adoption of the Rome Statute of the ICC in July $1998 .^{11}$

A similar process can be discerned with respect to "war crimes." Although they were well recognized in international law even prior to World War II, violations were confined to international armed conflict. The 1949 Geneva Conventions added important obligations, requiring that states ensure the repression of war crimes through investigation, prosecution, or, where appropriate, extradition. However, these duties applied only to a rather narrow subset of war crimes known as "grave breaches."

And so, by the end of the 1940s, this is how things stood. Within international armed conflict, criminal law authorized the prosecution of war crimes, crimes against humanity, and genocide. It imposed an obligation to prosecute, however, only with respect to genocide and "grave breaches" of the Geneva Conventions. It implicitly recognized universal jurisdiction with respect to grave breaches, but not with respect to genocide, crimes against humanity, or war crimes falling short of grave breaches. The only violations punishable when committed in peacetime, or in non-international armed conflict, had to meet the narrow confines of the definition of genocide. The only treaty obligation conferring jurisdiction upon the International Court of Justice was found in the UNCG. There was a duty to prevent-today we might call this the "responsibility to protect"-with respect to violations of the Geneva Conventions committed in international (but not non-international) armed conflict and with respect to genocide.

This was a confusing patchwork indeed. Experts might quarrel with a few of the distinctions I have made as to the obligations that obtained at the time. But some general themes are unquestionable. By the end of the 1940s there were the very clear beginnings of the elaborate system of international humanitarian law that we know today. But it was characterized by drastic limitations with respect to the definitions of crimes and the obligations they imposed.

Today, all of this has changed. It is this dramatic development that provides the underpinning for Scheffer's proposal.

Here is where things stand today: the concepts of "crimes against humanity" and "war crimes" have been dramatically extended so that there is now a relatively seamless body of "atrocity law" covering all serious violations of human rights. Variously defined as grave breaches, violations of the laws or customs of war, crimes against humanity, genocide, and serious violations of international humanitarian law, they ensure that all atrocities are subject to international criminal prosecution. The obligations that flow from these definitions are also much expanded from the 1940s. It is now generally agreed that universal jurisdiction applies to all serious violations of international humanitarian law. Some 104 states have now confirmed this obligation by ratifying the Rome Statute of the ICC. Besides imposing the obligation on them as a matter of treaty law, it also ensures that where national justice systems fail, the ICC may step in. Finally, it is accepted that states also have a duty to intervene through collective action where such acts are taking place in other countries. This "responsibility to protect" was affirmed in the 2005 Outcome Document, as has already been explained.

The result, then, is that there are almost no distinctions to be made in terms of the legal consequences that flow from characterizing a crime as "genocide," 
or "crimes against humanity," or "war crimes." There is only one difference of any significance: the 1948 UNCG gives jurisdiction to the International Court of Justice in the event of disputes between state parties. No comparable provision exists for crimes against humanity or war crimes. Still, even states that have not ratified the UNCG but have accepted the general jurisdiction of the International Court of Justice may be sued in that forum for serious violations of international humanitarian law and human-rights law, as the 19 December 2005 judgment in the case of Democratic Republic of Congo $v$. Uganda demonstrated. ${ }^{12}$

The logical consequence of Scheffer's suggestion may be to abandon altogether use of the terms "genocide," "crimes against humanity," and "war crimes." He doesn't say this, but others will surely draw such a conclusion, or suggest that this is the implied consequence. In terms of international law, he is absolutely right. As I have explained, there is no longer any meaningful legal distinction between the various categories. Prosecutions will be streamlined, and intervention facilitated, by putting an end to quarrels about the technical definitions of such crimes, much of them drafted in "archaic" terminology (George W. Bush's former Attorney General would say "quaint").

Of course, the term "genocide" will not disappear. Its place in the English language (and others, too) is simply too important. But future debates may be more about symbolism than about legal detail. To the Armenians, for example, it seems terribly important that their victimization be described as "genocide." It is doubtful that they could compromise with the Turks by calling the events of 1915 an "atrocity," or even "crimes against humanity" for that matter (although that was the taxonomy at the time). ${ }^{13}$ But this is not simply a matter of historical usage. Even today, there is animated debate about whether or not the atrocities being committed in Darfur should be described as genocide. The 2005 Commission of Inquiry said they shouldn't, but went on to explain that as crimes against humanity and war crimes the acts perpetrated were just as serious. Like genocide, they are subject to universal jurisdiction, to international prosecution, and to a duty to intervene (as the Outcome Document confirmed later the same year). Yet the impeccable reasoning of the Darfur commission has hardly deterred its critics, who have condemned the refusal to use the term "genocide" as trivialization and betrayal.

Once we agree that most of the legal nuances that once justified treating "genocide" as a distinct category no longer apply, the usage of the term is free to evolve. There are two directions in which this evolution can take place. One would be to insist upon a narrow construction so as to preserve the terrible stigma associated with the word. The other is to broaden genocide's scope so that it covers a range of atrocities falling short of the intentional destruction of a national, ethnic, racial, or religious group. In the past, the second view tended to prevail, reflected in much of the academic literature as well as in expert studies, such as Ben Whitaker's report to the UN Sub-Commission on Human Rights. ${ }^{14}$ But to a large extent the momentum to enlarge the definition of genocide came from frustration at the incomplete coverage that international law provided for atrocity crimes. Until recently, there was lingering uncertainty about international criminal responsibility for crimes against humanity committed in peacetime, or for war crimes committed in international armed conflict. In 1994 many argued for a duty to intervene not because there was some overarching "responsibility to protect" in the event of genocide, crimes against humanity, war crimes, and ethnic cleansing - a premise that seemed dubious at the time in public international law-but because the argument for intervention was premised on the 
text of the UNCG, where a duty to prevent was set out (albeit vaguely). Ditto in 1999 with respect to Kosovo. That is what drove David Scheffer's campaign for recognition of an antechamber of genocide known as "precursors," as his article explains.

My preference would be to restrict the definition of genocide in order to ensure its stigma. I understand the views of those who see things otherwise, and respect their opinions. Because we are now dealing with semantics rather than law, the final judgment is more likely to be determined by the editors of the Oxford English Dictionary than by judges in some international tribunal. Linguistic quibbles notwithstanding, there can be little doubt that, in terms of the substance of serious violations of international humanitarian law, the historic boundaries have largely disappeared. From this perspective, David Scheffer's proposal makes good sense.

\section{Notes}

1. L.C. Green, “Grave Breaches' or Crimes against Humanity," United States Air Force Academy Journal of Legal Studies 8 (1997/1998): 19-36; William J. Fenrick, "Should Crimes against Humanity Replace War Crimes?" Columbia Journal of Transnational Law 37 (1999): 767-88.

2. Prosecutor v. Tadić, Decision on the defence motion for interlocutory appeal on jurisdiction, ICTY-94-1-AR72 (2 October 1995).

3. Report of the International Commission of Inquiry on Darfur to the United Nations Secretary-General, UN Doc. S/2005/60 (25 January 2005), http://www.un.org/News/dh/ sudan/com_inq_darfur.pdf (accessed 3 January 2007), para. 533 (original emphasis).

4. Outcome Document of the 2005 World Summit, UN Doc. A/RES/60/1 (24 October 2005), paras. $138-39$.

5. "Agreement for the Prosecution and Punishment of the Major War Criminals of the European Axis, Charter of the International Military Tribunal," 8 August 1945, United Nations Treaty Series 14, p. 280, art. VI(c).

6. "Minutes of Conference Session of July 23, 1945," in Report of Robert H. Jackson, United States Representative to the International Conference on Military Trials (Washington, DC: US GPO, 1949): 328-47, 331.

7. Ibid., 333 .

8. France et al. v. Göring et al., (1946) 22 IMT 203, 13 ILR 203, American Journal of International Law 41 (1946): 172.

9. Official Records of the First Session of the General Assembly, Legal Questions, Sixth Committee, Summary Record of Meetings, UN Doc. A/C.6/SR.22 (29 October 1946).

10. Convention on the Prevention and Punishment of the Crime of Genocide, 9 December 1948, 78 U.N.T.S. 277.

11. Rome Statute of the International Criminal Court, U.N. Doc. A/CONF.183/9 (17 July 1998).

12. Case Concerning Armed Activities on the Territory of the Congo (Democratic Republic of the Congo v. Uganda), International Court of Justice, 19 December 2005. See also Legal Consequences of the Construction of a Wall in the Occupied Palestinian Territory, Advisory Opinion, International Court of Justice, 9 July 2004.

13. On 24 May 1915 the governments of France, Great Britain, and Russia made a declaration asserting that "in the presence of these new crimes of Turkey against humanity and civilization, the allied Governments publicly inform the Sublime Porte that they will hold personally responsible for the said crimes all members of the Ottoman Government as well as those of its agents who are found to be involved in such massacres." English translation quoted in United Nations War Crimes Commission, History of the United Nations War Crimes Commission and the Development of the Laws of War (London: HMSO, 1948), 35.

14. Benjamin Whitaker, Revised and Updated Report on the Question of the Prevention and Punishment of the Crime of Genocide, UN Doc. E/CN.4/Sub.2/1985/6 (2 July 1985). 